\title{
Chemical Composition of Earthworm (Eisenia foetida) Co-Dried with Vegetable Meals as an Animal Feed
}

\author{
Kirenia Pérez-Corría ${ }^{1}$ \\ Aroldo Botello-León ${ }^{2}$ \\ Abril Karina Mauro-Félix ${ }^{3}$ \\ Franklin Rivera-Pineda ${ }^{4}$ \\ María Teresa Viana ${ }^{5}$ \\ Maribel Cuello-Pérez ${ }^{6}$ \\ Arnaldo Botello-Rodríguez ${ }^{7}$ \\ Yordan Martínez-Aguilar ${ }^{8}$
}

Fecha de recepción: 2 de febrero de 2019

Fecha de aceptación: 25 de marzo de 2019

\begin{abstract}
To evaluate the chemical composition of the earthworm (Eisenia foetida) co-dried (EW) with vegetable meals (VM) as animal feed ingredient, the blends were mixed with wheat bran (WB), rice powder (RP), corn meal (CM) and soy cake meal (SCM) in proportions of $85: 15 ; 75: 25$ and $65: 35$. The dry matter (DM), crude protein (CP), crude fat (CFA), crude fiber (CF), ashes and nitrogen-free extract (NFE) of the ingredients and final mixtures were determined. All the mixtures resulted with a high content of DM $(\geq 90.00 \%)$. No significant differences among the proportions were revealed $(P>0.05)$. In addition, the higher inclusion of the earthworm in the proportions $(85: 15)$ increased $(P<0.05)$ the CP $(54.70 \%)$, CFA $(7.28 \%)$, and ashes $(10.20 \%)$, mainly when mixed with SCM, CM, and RP, respectively. However, the use of vegetable meals proportionally increased the CF $(7.31 \%)$, and NFE $(52.62 \%)$, mainly with the proportion of $65: 35$ and with RP and $\mathrm{CM}$, respectively $(P<0.05)$. The results showed that the vegetable meals (WB, RP, $\mathrm{CM}$, and SCM) are useful to co-dry the earthworm to be use for animal feed. It is concluded that the most appropriate proportion (VM:EW) will depend on the animal species, productive stage and market requirement.
\end{abstract}

Keywords: corn meal; earthworm; protein source; rice powder; soy cake meal; wheat bran.

\footnotetext{
${ }^{1}$ M. Sc. Universidad Técnica Luis Vargas Torres (Esmeraldas, Ecuador). kirenia.perez@utelvt.edu.ec. ORCID: 0000-00020216-328X.

${ }^{2}$ Ph. D. Universidad Técnica Luis Vargas Torres (Esmeraldas, Ecuador). aroldo.botello@utelvt.edu.ec. ORCID: 0000-00016709-2104.

${ }^{3}$ Universidad Intercultural del Estado de México (México D.C., México). ORCID: 0000-0002-1775-631X.

${ }^{4}$ Ph. D. Universidad Intercultural de Chiapas (Chiapas, México). franklin.rivera@unich.edu.mx. ORCID: 0000-0002-1273-2730.

${ }^{5}$ Ph. D. Instituto de Investigaciones Oceanológicas-Universidad Autónoma de Baja California (Baja California, México). viana@uabc.edu.mx. ORCID: 0000-0002-3074-767X.

${ }_{6}^{6}$ Ph. D. Universidad Técnica Luis Vargas Torres (Esmeraldas, Ecuador). maribel.cuello@utelvt.edu.ec. ORCID: 0000-00027086-6075.

${ }^{7}$ Ph. D. Universidad Oscar Lucero (Holguín, Cuba). ORCID:0000-0001-7298-4772.

${ }_{8}^{8}$ Ph.D. Escuela Agrícola Panamericana (Francisco Morarán, Honduras). ymartinez@zamorano.edu. ORCID: 0000-0003-2167$\underline{4904}$.

Ciencia y Agricultura (Cien. Agri.) Vol. 16 (2). L-ISSN 0122-8420. elSSN 2539-0899.

Mayo-Agosto 2019, pp. 79-92. Tunja (Boyacá) - Colombia. DOI: https://doi.org/10.19053/01228420.v16.n2.2019.9130
} 


\section{Composición química de la lombriz de tierra (Eisenia foetida) presecada con harinas vegetales como alimento animal}

\section{Resumen}

Para evaluar la composición química de la lombriz de tierra (Eisenia foetida) (LT) presecada con harinas vegetales (HV) como alimento animal, las mezclas se secaron individualmente y se elaboraron distintas premezclas con salvado de trigo (ST), polvo de arroz (PA), harina de maíz (HM) y harina de pasta de soya (HPS) en proporciones de 85:15; 75:25 y 65:35. Se determinó la materia seca (MS), proteína cruda (PC), grasa cruda (GC), fibra cruda (FC), cenizas y extracto libre de nitrógeno $(E L N)$ de los ingredientes y de las mezclas finales. Todas las mezclas mostraron un alto contenido de MS ( $\geq 90.00 \%)$. No se revelaron diferencias significativas entre las proporciones $(P>0.05)$. La mayor inclusión de la lombriz de tierra en las proporciones (85:15) incrementó $(P<0.05)$ la $\mathrm{PC}, \mathrm{GC}$ y cenizas, principalmente cuando se mezcló con la harina de soya, harina de maíz y polvo de arroz, respectivamente. Sin embargo, el uso de las harinas vegetales incrementó proporcionalmente la FC (7,31\%) y el ELN (52.62\%), especialmente con la proporción de 65:35 y con PA y HM, respectivamente $(P<0.05)$. Los resultados mostraron que las harinas de vegetales (WB, RP, CM y SCM) son útiles para presecar la lombriz de tierra para uso en la alimentación animal. Se concluye que la proporción más adecuada (VM:EW) dependerá de las especies animales, la etapa productiva y los requisitos del mercado.

Palabras clave: fuente de proteína; harina de maíz; harina de pasta de soya; lombriz de tierra; polvo de arroz; salvado de trigo.

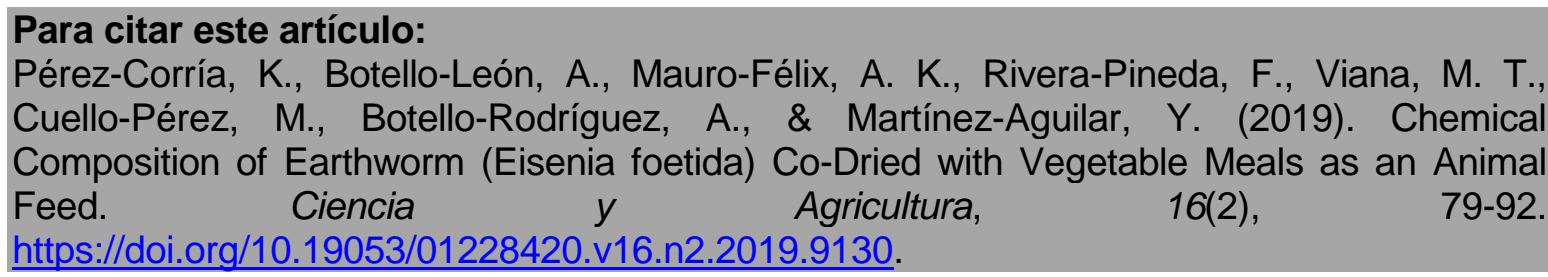

Esta obra está bajo licencia internacional Creative Commons Reconocimiento 4.0

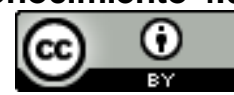




\section{INTRODUCTION}

The world population is growing rapidly and it is expected to reach between 8.5 and 12 billion by the year 2100 , of which $75 \%$ of the population will live in the countries of Africa and Asia, which are mostly developing countries. Currently, human overpopulation is related to food insecurity, which induces the evolution of resource-exhaustive agriculture causing irreparable environmental damage (Singh, Srivastava, Singh,Upadhyay \& Raghubanshi, 2019). FAO suggests that global food production will need to double in the future (Smárason, Alriksson \& Jóhannsson, 2018; Øverland, Mydland \& Skrede, 2019). Therefore, the challenge for agricultural producers is to use efficiently the environmental resources to transform them into animal feed (Mohanta, Subramanian \& Korikanthimath, 2016; Sánchez et al., 2019).

In production systems of non-ruminant species, feed represents the highest cost of the zootechnical production, especially in developing countries, where the prices of raw materials are inaccessible for mid and small producers (Olmo et al., 2012). In particular, conventional protein sources, such as fishmeal and soybean meal (Smárason et al., 2018). Several unconventional or alternative feeds have been used as protein sources to reduce production costs. Among the most remarkable are the protein fodders, yeasts, oilseeds, and the earthworm (Bahadori et al., 2017; Duodu et al., 2018; Falowo et al., 2018).

In this sense, the earthworm (Eisenia foetida), a species of domesticated earthworm, obtained as the final product of vermicomposting (Guptaa, Shikhab \& Tewaria, 2014; Yang, Wang, Wang, Du \& Zhang, 2015; Sharma \& Garg, 2018; Maková et al., 2019), is an eco-friendly, cost-effective, zero waste technology which can be used to convert non-toxic organic waste residues into valuable product (vermicompost). Vermicompost is environmentally friendly organic manure having high quantities of humic acids, plant growth hormones, enzymes and antimicrobial substances (Coulis et al., 2014; Kızılkaya \& Türkay, 2014; Maková et al., 2019).

The earthworm (Eisenia foetida) has been considered an integral product for animal feed, it has a high content of crude protein (from 60 to $70 \%$ on dry basis) (Ibáñez, Herrera, Velásquez \& Hebel, 1993; Sogbesan \& Ugwumba, 2008; Rezaeipour, Nejad \& Miri, 2014; Ncobela \& Chimonyo, 2015) and essential amino acids deficient in many vegetable meals commonly used in diets such as lysine, threonine, arginine and valine. Besides, fatty acids of biological importance have been detected, such as octadecanoic acid (C18:0) linoleic acid (C18:2) and linolenic acid (C18: 3) (Zhenjun, Xianchun, Lihui \& Chunyang, 1997; Tiroesele \& Moreki, 2012; Gunya, Masika, Hugo \& Muchenje, 2016). Other nutrients such as copper, iron, manganese, zinc, and phosphorus have been found in significant amounts (Gunya et al., 2016).

The earthworm meal (EW) has been used to prepare a typical local food "arepas" for human consumption (Cayot et al., 2009). However, its most widespread use is as animal feed. Thus, the inclusion of up to $30 \%$ in diets for broilers improved the growth and meat quality (Bahadori, Esmaylzadeh \& Torshizi, 2015). Likewise,

Ciencia y Agricultura (Cien. Agri.) Vol. 16 (2). L-ISSN 0122-8420. elSSN 2539-0899.

Mayo-Agosto 2019, pp. 79-92. Tunja (Boyacá) - Colombia. DOI:

https://doi.org/10.19053/01228420.v16.n2.2019.9130 
prawns (Macrobrachium dayanum) fed earthworm meal had a higher weight gain $(0.3 \pm 0.02)$, survival $(90 \%)$ and feed conversion ratio $(0.9 \pm 0.01)$ compared to silkworm pupae and soybean meal (Langer, Bakhtiyar \& Lakhnotra, 2011). Other studies have shown that the use of EW at 15.8, 23 and $12.5 \%$ in the diets of Wistar laboratory rats, black cachama fingerlings (Colossoma macropomum) and rabbits improved the overall performance without affecting the health of these animals, respectively (García, Oruña, Domínguez \& Martínez, 2005; Morillo, Visbal, Altuve, Ovalles \& Medina, 2013; Kuforiji, Agunbiade, Awojobi \& Eniolorunda, 2016).

On the other hand, the feed drying technology is the process where heat is applied to remove the water by evaporation, with the purpose of extending the useful life by reducing the activity of the water; the methods used depend on the type and quantity of product, water level to eliminate and the final quality. This process intervenes in the mechanical, sensory and nutritional properties of feed and can be used to create new functionalities, being one of the main techniques for the conservation of agricultural products (Bonazzi \& Dumoulin, 2011).

In this sense, the main drawback of the use of EW is the high moisture content (from 80 to $85 \%$ ) (Cayot et al., 2009; Morillo et al., 2013). Therefore, a low-cost method to facilitate the drying will be essential to make successful this process. Thus, the codrying process is one of the most efficient alternatives, by mixing the earthworms. Besides, the nutritional value of this feed for livestock would be increased (Goddard \& Perret, 2005; Botello et al., 2011; Botello et al., 2017). Studies by Gunya et al. (2016) demonstrated that oven-dried and freeze-dried were efficient methods for earthworms. Therefore, the objective of this work was to evaluate the chemical composition of the earthworm mixed with vegetable meals as animal feed.

\section{MATERIALS AND METHODS}

\section{A. Obtaining the earthworm}

Three months of age $(8.3 \mathrm{~cm}$ length and $0.4 \mathrm{~g}$ average) earthworm (Eisenia foetida) were obtained by culturing using bovine manure as feed. The culture parameters, such as temperature, humidity, and $\mathrm{pH}$ of the manure were taken into account to guarantee optimal growth conditions. At harvest, the earthworms were washed and cleaned by keeping them for 12 hours in aerated fresh water. The clean earthworm was boiled in water for $1 \mathrm{~min}$, and then ground in a meat mill with a sieve of $2 \mathrm{~mm}$ in diameter (Cayot et al., 2009).

\section{B. Preparation of mixtures}

The earthworms (EW) already processed, were individually and homogeneously mixed with the vegetable meals (VM): wheat bran (WB), rice powder (RP), corn meal (CM), and soybean cake meal (SCM), according to the following proportions: 85:15, 75:25 and 65:35 (EW:VM). Three $\mathrm{kg}$ of each mixture was made. All the combinations were individually sun dried for 72 hours before they were ground in a hammer mill with a $1 \mathrm{~mm}$ sieve. 


\section{Chemical characterization of feeds and mixtures}

Each ingredient and its blends were taken in triplicate groups of $100 \mathrm{~g}$. Dry matter (DM), crude protein (CP), crude fat (CFA), crude fiber (CF), ashes and nitrogen-free extract (NFE) were determined according to the AOAC (2011). The chemical composition of the feed ingredient used in the different mixtures is shown in Table 1.

Table 1. Chemical composition of the feed ingredients (as feed).

\begin{tabular}{cccccc}
\hline \multirow{2}{*}{ Items } & \multicolumn{5}{c}{ Feed ingredients } \\
\cline { 2 - 6 } & Earthworm & Wheat bran & Rice powder & Corn meal & $\begin{array}{c}\text { Soybean } \\
\text { cake meal }\end{array}$ \\
\hline DM & $19.52 \pm 0.301$ & $90.17 \pm 0.200$ & $91.20 \pm 0.318$ & $90.74 \pm 0.284$ & $90.23 \pm 0.217$ \\
CP & $13.76 \pm 0.313$ & $13.36 \pm 0.193$ & $10.45 \pm 0.065$ & $9.19 \pm 0.163$ & $43.16 \pm 0.513$ \\
CFA & $2.06 \pm 0.045$ & $3.76 \pm 0.183$ & $8.48 \pm 0.199$ & $4.68 \pm 0.200$ & $1.82 \pm 0.085$ \\
CF & - & $10.24 \pm 0.147$ & $7.02 \pm 0.085$ & $2.84 \pm 0.259$ & $4.25 \pm 0.142$ \\
Ashes & $2.53 \pm 0.117$ & $5.86 \pm 0.147$ & $7.57 \pm 0.202$ & $2.03 \pm 0.062$ & $5.75 \pm 0.140$ \\
NFE & $1.18 \pm 0.063$ & $56.96 \pm 0.250$ & $57.68 \pm 0.458$ & $72.00 \pm 0.426$ & $35.25 \pm 0.719$ \\
\hline
\end{tabular}

Mean; \pm Standard Deviation

\section{Statistical analysis}

Data obtained from the chemical composition of feed ingredients and EW were analyzed through the descriptive statistics model, the mean and the standard deviation were determined. Also, data from the chemical composition of the mixtures $(65: 35 ; 75: 25 ; 85: 15)$ with VM and EW were processed by analysis of variance (ANOVA) of simple classification, in completely randomized design. In the necessary cases Duncan's test was applied to determine mean differences. The statistical software INFOSTAT version 2017 was used.

\section{RESULTS}

The mixtures with EW+WB indicated more than $90.00 \%$ DM (Table 2), without significant differences ( $P>0.05)$ among treatments. However, a higher proportion with $\mathrm{EW}$ in the mixture $(85: 15)$ increased $(P<0.05)$ the content of $\mathrm{CP}(27.85$ to 41.09 $\%)$, CFA (6.86 to $5.40 \%)$ and ashes $(7.57$ to $9.11 \%)$ and decreased $(P<0.05)$ the CF $(7.31$ to $4.59 \%)$ and NFE (42.20 to $28.59 \%)$ compared to the lowest proportions of this protein product (EW) (65:35 and 75:25) (Table 2).

Table 2. Chemical composition of the mixture with EW+WB (as feed).

\begin{tabular}{ccccccc}
\hline Proportions & \multicolumn{7}{c}{ Chemical composition (\%) } \\
\cline { 2 - 7 } (EW:WB) & DM & CP & CFA & CF & Ashes & NFE \\
\hline $85: 15$ & 90.24 & $41.09^{\mathrm{a}}$ & $6.86^{\mathrm{a}}$ & $4.59^{\mathrm{c}}$ & $9.11^{\mathrm{a}}$ & $28.59^{\mathrm{c}}$ \\
$75: 25$ & 90.42 & $33.26^{\mathrm{b}}$ & $6.01^{\mathrm{b}}$ & $6.22^{\mathrm{b}}$ & $8.21^{\mathrm{b}}$ & $36.72^{\mathrm{b}}$ \\
$65: 35$ & 90.33 & $27.85^{\mathrm{c}}$ & $5.40^{\mathrm{c}}$ & $7.31^{\mathrm{a}}$ & $7.57^{\mathrm{b}}$ & $42.20^{\mathrm{a}}$ \\
SEM \pm & 0.111 & 1.924 & 0.219 & 0.399 & 0.244 & 1.981 \\
$P$-value & 0.839 & $<0.0001$ & $<0.0004$ & $<0.0001$ & $<0.0042$ & $<0.0001$ \\
\hline
\end{tabular}

$\overline{\mathrm{a}, \mathrm{b}, \mathrm{c}}$ Different superscripts within the columns differ significantly $(P<0.05) . \mathrm{n}=3$. 
Table 3 shows that the mixtures $(\mathrm{EW}+\mathrm{RP})$ did not demonstrate statistical differences $(P>0.05)$ for DM (90.72 to $90.86 \%)$. However, the highest proportion with EW increased the CP proportionally (25.28 to $37.39 \%)$, CFA (7.14 to $8.94 \%$ ) and ashes $(9.26$ to $10.20 \%)$. As well as the greater use of fibrous feed (RP) in the mixture increased the content $(P<0.05)$ of CF $(3.36$ to $4.83 \%)$ and NFE (30.83 to $44.28 \%)$.

Table 3. Chemical composition of the mixture with EW+RP (as feed).

\begin{tabular}{ccccccc}
\hline $\begin{array}{c}\text { Proportions } \\
\text { (EW:RP) }\end{array}$ & DM & CP & CFA & CF & Ashes & NFE \\
\cline { 2 - 7 } & 90.72 & $37.39^{\mathrm{a}}$ & $8.94^{\mathrm{a}}$ & $3.36^{\mathrm{c}}$ & $10.20^{\mathrm{a}}$ & $30.83^{\mathrm{c}}$ \\
$85: 15$ & 90.86 & $31.00^{\mathrm{b}}$ & $7.90^{\mathrm{b}}$ & $3.88^{\mathrm{b}}$ & $9.65^{\mathrm{ab}}$ & $38.43^{\mathrm{b}}$ \\
$75: 25$ & 90.79 & $25.28^{\mathrm{c}}$ & $7.14^{\mathrm{c}}$ & $4.83^{\mathrm{a}}$ & $9.26^{\mathrm{b}}$ & $44.28^{\mathrm{a}}$ \\
$65: 35$ & 0.068 & 1.752 & 0.267 & 0.224 & 0.161 & 1.950 \\
SEM \pm & 0.749 & $<0.001$ & $<0.001$ & $<0.001$ & 0.024 & $<0.001$ \\
P-value & 0.750 &
\end{tabular}

a,b,c Different superscripts within the columns differ significantly $(P<0.05)$. $\mathrm{n}=3$.

The DM (90.17 to $90.27 \%$ ) did not vary statistically ( $>0.05$ ) in the mixtures of the EW with a cereal (CM) (Table 4). Similar to the other combinations, the higher inclusion of the protein source (EW) caused a significant increase $(P<0.05)$ in the CP (24.68 to $39.25 \%$ ), CFA (6.02 to $7.28 \%$ ), and ashes (4.80 to $7.40 \%$ ). Meanwhile, a higher proportion of CM increased CF and NFE (Table 4).

Table 4. Chemical composition of the mixture with $\mathrm{EW}+\mathrm{CM}$ (as feed).

\begin{tabular}{ccccccc}
\hline Proportions & \multicolumn{7}{c}{ Chemical composition (\%) } \\
\cline { 2 - 7 } (EW:CM) & DM & CP & CFA & CF & Ashes & NFE \\
\hline $85: 15$ & 90.27 & $39.25^{\mathrm{a}}$ & $7.28^{\mathrm{a}}$ & $1.29^{\mathrm{c}}$ & $7.40^{\mathrm{a}}$ & $35.05^{\mathrm{c}}$ \\
$75: 25$ & 90.02 & $30.57^{\mathrm{b}}$ & $6.53^{\mathrm{b}}$ & $1.74^{\mathrm{b}}$ & $5.85^{\mathrm{b}}$ & $45.32^{\mathrm{b}}$ \\
$65: 35$ & 90.17 & $24.68^{\mathrm{c}}$ & $6.02^{\mathrm{c}}$ & $2.04^{\mathrm{a}}$ & $4.80^{\mathrm{c}}$ & $52.62^{\mathrm{a}}$ \\
SEM \pm & 0.073 & 2.116 & 0.189 & 0.110 & 0.379 & 2.550 \\
P-value & 0.408 & $<0.001$ & $<0.001$ & 0.001 & $<0.001$ & $<0.001$ \\
\hline a,b,c Different superscripts within the columns differ significantly $(P<0.05) . \mathrm{n}=3$.
\end{tabular}

The use of the EW in the SCM mixture increased $(P<0.05)$ the contents of CP $(49.16$ to $54.90 \%$ ), CFA (4.00 to $6.02 \%$ ) and ashes (7.51 to $9.14 \%$ ), being significantly higher with the proportion of 85: 15 (Table 5). However, this proportion (85:15) consistently reduced the CF (1.93 to $3.05 \%$ ) and NFE (18.52 to $26.56 \%$ ), without statistically modifying the DM of the mixtures ( $P>0.05$; Table 5).

Table 5. Chemical composition of the mixture with EW+SCM (as feed).

\begin{tabular}{ccccccc}
\hline Proportions & \multicolumn{7}{c}{ Chemical composition (\%) } \\
\cline { 2 - 7 } (EW:SCM) & DM & CP & CFA & CF & Ashes & NFE \\
\hline $85: 15$ & 90.52 & $54.90^{\mathrm{a}}$ & $6.02^{\mathrm{a}}$ & $1.93^{\mathrm{c}}$ & $9.14^{\mathrm{a}}$ & $18.52^{\mathrm{c}}$ \\
$75: 25$ & 90.37 & $51.70^{\mathrm{b}}$ & $4.84^{\mathrm{b}}$ & $2.61^{\mathrm{b}}$ & $8.20^{\mathrm{b}}$ & $23.02^{\mathrm{b}}$ \\
$65: 35$ & 90.28 & $49.16^{\mathrm{c}}$ & $4.00^{\mathrm{c}}$ & $3.05^{\mathrm{a}}$ & $7.51^{\mathrm{c}}$ & $26.56^{\mathrm{a}}$ \\
SEM \pm & 0.084 & 0.831 & 0.296 & 0.167 & 0.238 & 1.165 \\
P-value & 0.563 & $<0.001$ & $<0.001$ & $<0.002$ & $<0.001$ & $<0.001$ \\
\hline
\end{tabular}

${ }^{\mathrm{a}, \mathrm{b}, \mathrm{c}}$ Different superscripts within the columns differ significantly $(P<0.05) . \mathrm{n}=3$.

Ciencia y Agricultura (Cien. Agri.) Vol. 16 (2). L-ISSN 0122-8420. elSSN 2539-0899.

Mayo-Agosto 2019, pp. 79-92. Tunja (Boyacá) - Colombia. DOI:

https://doi.org/10.19053/01228420.v16.n2.2019.9130 


\section{Discussion}

The goal of this study was to evaluate whether the EW (80.48\% of humidity) codried with different vegetal meals (with more $90.00 \%$ of DM) would reduce the moisture and improve the nutritional composition of the final combinations, to be used for non-ruminant species (mainly) and aquatic organisms. It is known that the EW is some feed source rich in CP (13.76 \%), CFA (2.06\%), with low ashes (2.53 $\%)($ Table I), with high content of essential amino acids such as lysine $(3.10 \%)$, phenylalanine $(2.90 \%)$, leucine $(13.80 \%)$, isoleucine $(5.30 \%)$, valine $(3.60 \%)$. Also, essential fatty acids are present, such as linoleic acid (Vielma, Durán, León \& Medina, 2003). Its inclusion in animal diets can replace conventional protein sources (fishmeal and soybean meal) to lower production costs (Gunya, Muchenje \& Masika, 2019). Besides, our research can contribute to the promotion of vermiculture in agricultural production systems (Kuforiji et al., 2016).

Several studies have been conducted to establish the most efficient drying process for the EW (Cayot et al., 2009; García et al., 2005; Boulogne, Márquez, Zambrano, Medina \& Cayot, 2008; Morillo et al., 2013; Bahadori et al., 2015; Ovalles, Medina, Márquez \& Rial, 2017). The drying process of the EW is a critical factor because specific proteins are denatured with heat. Although the primary structure of the proteins (the amino acid sequence linked by peptide bonds) is not interrupted by the denaturation, the secondary-quaternary structures could be affected with consequences in the digestibility. The transformation method of earthworm biomass in meal can affect the quality of this feed product, especially the amino acid profile (Boulogne et al., 2008; Córdova, Anaya, Ovando, García \& Silvano, 2013; Martínez et al., 2017; Ovalles et al., 2017).

In turn, Boulogne et al. (2008), after a shorter drying time of earthworm meal (Eisenia andrei) previously subjected to a pressing, found that it resulted in the disadvantage of $6 \%$ loss of soluble protein. In the present work it is demonstrated a viable alternative as co-drying process using the EW mixed with different vegetable sources, increasing the DM content without the loss of soluble protein or deteriorating the protein quality of the EW.

In this sense, we found several researches using vegetable meals as a co-drying of semi-liquid feed. Some authors have used vegetable meals (wheat bran, rice powder, corn meal and soybean cake meal) to decrease the moisture content (up to $75 \%)$ of different fish silages, which facilitates the drying and improved the nutritional composition of various feed sources to be used as a protein for feed on animal diets (Fagbenro, 1994; Vidotti \& Carneiro, Viegas, 2002; Goddard \& Perret, 2005; Botello et al., 2017). Wheat bran (WB) is one of the most used vegetable sources with large worldwide distribution. This source is a by-product of the wheat milling process, resulting in high levels of CF (10.60 to $13.63 \%)$, containing a lower metabolizable energy (ME) than that obtained with corn, sorghum or barley (National Research Council [NRC], 1994). 
In our work, the WB was used as a support to simplify the co-drying of the EW (in the form of semi-liquid feed) and the final mixture reached $90.00 \%$ of DM in the three combinations (Table II), increasing the protein content from the vegetable source up to $34.07 \% \mathrm{CP}$. The crude protein, the most essential macronutrient in the animal nutrition, due to the supply of essential amino acids for growth, maintenance and tissue repair, as well as hormones, enzymes, antibodies, and other organic constituents (Martínez et al., 2017). In this regard, Goddard y Perret (2005) found a DM content higher than $90 \%$ with an average CP values of $50.00 \%$ when mixing sardine fish silage with wheat bran.

As it is known, animal source foods such as the EW do not have CF, however, the use of WB was increased to the carbohydrates at 7.31\%, in the proportion 65:35 (Table II). Fiber is essential for the intestinal health of non-ruminant species, helping the digestive functioning of enzymes, for the immune response modulation in the gastrointestinal tract (GIT) (Savón, Scull \& Martínez, 2007). Modulation that is reached through a competitive exclusion, increasing the production of acids volatile fatty acids, reducing the intestinal $\mathrm{pH}$ by the emission of protons, increasing the energy contribution of the ration and reducing the serum cholesterol. Nevertheless, high levels of fiber cause the loss of digestible energy (Căpriţă, Căpriţă \& Julean, 2010; Valverde, 2010; Falcón, Barrón, Romero \& Domínguez, 2011), which reduces the bioavailability of minerals and negatively affects the performance of animals (Jiménez, Coca, González \& Mateos, 2016; Rojas, Vinyeta \& Stein, 2016).

The co-drying of the EW with a vegetable meal such as RP resulted in a blend with high content of DM, CP (31.22\%) and NFE in all used proportions. However, the CF significantly increased by $4.83 \%(P<0.05)$ accordingly the plant material added. A combination that could favor the nutrition of laying pullets, empty sows, rabbits and adult fish (Martínez et al., 2015). In this sense, Vidotti et al. (2002) found that mixing an acid fish silage with rice powder (50:50) improved the profile of essential amino acids, facilitating the storage and transportation of the final product. Although RP provides few essential amino acids, its main contribution was the decrease of moisture from the initial product to obtain an alternative feed protein (Table III), to replace conventional feed protein (fishmeal and soybean meal), generally imported from developing countries.

Regarding the corn, which is highly palatable and easily digestible by non-ruminant and ruminant animals, and considered one of the best sources of ME, containing approximately $72.0 \%$ of starch, low fiber and protein level and deficient essential amino acids such as lysine and tryptophan (Szulc, Podkowaka, Bocianowski, Krauklis \& Wilczewska, 2018), the combinations of EW with CM resulted in CP values between 24.68 to $39.25 \%$; fat from 6.02 to $7.28 \%$ and CF up to $2.04 \%$, with a final DM of $90.10 \%$ (Table IV). In turn, Botello et al. (2017) found that CM reduced the moisture level of residual tilapia, with dry matter content higher than $90.00 \%$ with CP contents between 21.13 to $36.11 \%$. Therefore, the co-drying process of EW with vegetable meal enables the storage and helps to mitigate the pollution of the 
aquatic environment, by converting a by-product of aquaculture into an alternative animal protein.

Soybean meal is considered the most important source of vegetable protein for animal feed, with high lysine and tryptophan content for fresh water animals. However, it is relatively poor in sulfur-containing amino acids. Therefore, the mixture of EW with these vegetable meals could result in an adequate amino acid balance, to formulate aquafeeds (Botello et al., 2017). The SCM mixed with the EW showed more than $90.00 \% \mathrm{DM}$ in the three combinations (Table V) and CP values resulted between 49.16 to $54.90 \%$ (Table III). Fagbenro (1994) obtained similar results when mixing the biological silage of fish with SCM in a 50:50 proportion, with values of $49.80 \% \mathrm{CP}$, which is related to the protein contribution of the two raw materials used.

The use of vegetable meals as a co-drying process of EW is a positive alternative source of protein for non-ruminant species. Variability in the nutritional composition was obtained, according to the type of VM and the level of EW used (Tables II, III, IV and V). The mixture with the highest CP level was the EW+SCM $(85: 15)$ and the lowest was the $\mathrm{EW}+\mathrm{CM}(65: 35)$, although the $85: 15$ proportion of $\mathrm{EW}+\mathrm{CM}$ resulted in the highest content of CFA. According to the CF and ashes contents, the mixture with the highest values was the EW+RP (65:35). The co-drying contributes to guarantee the useful life of feeds, reducing the moisture, harmful microorganisms, and chemical reactions for enzymatic inhibition, which could facilities the storage and cost reduction and improve microbiological and nutritional quality of the feeds (Agrahar \& Jha, 2010; Erbay \& Hepbasli, 2014).

\section{CONCLUSIONS}

It is concluded that the process of co-drying earthworms with vegetable sources such as rice, wheat bran, corn meal and soybean cake improves the preservation at low cost of earthworms; also, by enrichment of the nutritional quality from the different vegetable sources by increasing the crude protein in particular. This new blend ingredient could replace conventional protein and fibrous ingredients for feed and feed formulations for different animal diets. The most appropriate proportions among vegetable meal to earth worm will be dependent to the animal species, productive stage and commercial market requirement.

\section{REFERENCES}

Agrahar, D., \& Jha, K. (2010). Effect of Drying of Nutritional and Functional Quality and Electrophoretic Pattern of Soyflour from Sprouted Soybean (Glycine max). Journal of Food Science and Technology, 47(5), 482487. http://doi.org/10.1007/s13197-010-0082-5.

AOAC (2011). Official Methods of Analysis of AOAC International (18 ${ }^{\text {th }}$ ed.). Maryland, USA: AOAC International.

Bahadori, Z., Esmaielzadeh, L., Karimi, M. A., Seidavi, A., Olivares, J., Rojas, S., Salem, A. Z., \& López, S. (2017). The Effect of Earthworm (Eisenia foetida) Meal with Vermi-Humus on Growth Performance, Hematology, Immunity, Intestinal Microbiota, Carcass Characteristics, and Meat Quality of Broiler Chickens. Livestock Science, 202(8), 74-81. http://doi.org/10.1016/j.livsci.2017.05.010. 
Bahadori, Z., Esmaylzadeh, L., \& Torshizi, M. A. (2015). The Effect of Earthworm (Eisenia fetida) and Vermihumus Meal in Diet on Broilers Chicken Efficiency and Carcass Components. Biological Forum, 7(1), 998-1005.

Bonazzi, C., \& Dumoulin, E. (2011). Quality Changes in Food Materials as Influenced by Drying Processes. In E. Tsotsas \& A.S. Mujumdar (eds.), Modern Drying Technology. Product Quality and Formulation (pp. 1-20). Berlin, Germany: Wiley VCH. https://doi.org/10.1002/9783527631667.ch1.

Botello, A. L., Cisneros, M., Viana, M. T., Valdivié, M., Ariza, E., Téllez, G. E., Solano, G., Rodríguez, Y., Gómez, I., Botello, A. R., Rodríguez, R., \& Corría, K. P. (2011). Utilization of Proteinic Sugarcane Meal in the Feeding of Juvenile Red Tilapia. Cuban Journal of Agricultural Science, 45(4), 411-415.

Botello, L. A., Viana, M. T., Corría, K. P., Marcos, O. O., Machado, R. T., Morán, M. C., Hurtado, G. K., Cedeño, T. D., López, C. K., López, B. J., Chacón, M. E., Zambrano, C. N., \& Ramírez, R. J. (2017). Caracterización nutricional y costos del residual de tilapia (Oreochromis niloticus) presecado con harinas vegetales. Revista Electrónica de Veterinaria, 18(4), 1-8.

Boulogne, S., Márquez, E., Zambrano, Y. E., Medina, A. L., \& Cayot, P. (2008). Optimización de la operación de secado de la carne de lombriz (Eisenia andrei) para producir harina destinada al consumo animal. Ciencia e Ingeniería, 29(2), 91-96.

Căpriţă, R., Căpriţă, A., \& Julean, C. (2010). Biochemical Aspects of Non-Starch Polysaccharides. Scientific Papers Animal Science and Biotechnologies, 43(1), 368-374.

Cayot, N., Cayot, P., Maroun, B. E., Laboure, H., Romero, A. B., Pernin, K., \& Medina, A. L. (2009). Physicochemical Characterisation of a Non-Conventional Food Protein Source from Earthworms and Sensory Impact in Arepas. International Journal of Food Science \& Technology, 44(11), 2303-2313. https://doi.org/10.1111/j.1365-2621.2009.02074.x.

Córdova, M. G., Anaya, A. M., Ovando, J. A., García, J. A., \& Silvano, E. J. (2013). Efecto del proceso de secado de la lombriz roja californiana (Eisenia foetida) en sus características nutricionales. Quehacer Científico en Chiapas, 8(2), 44-50.

Coulis, M., Bernard, L., Gérard, F., Hinsinger, P., Plassard, C., Villeneuve, M., \& Blanchart, E. (2014). Endogeic Earthworms Modify Soil Phosphorus, Plant Growth and Interactions in a Legume-Cereal Intercrop. Plant and Soil, 379(1-2), 149-160. https://doi.org/10.1007/s11104-014-2046-4.

Duodu, C. P., Boateng, A. D., Edziyie, R. E., Agbo, N. W., Boateng, O. G., Larsen, B. K., \& Skov, P. V. (2018). Processing Techniques of Selected Oilseed By-Products of Potential Use in Animal Feed: Effects on Proximate Nutrient Composition, Amino Acid Profile and Antinutrients. Animal Nutrition, 4(4), 442-451. https://doi.org/10.1016/j.aninu.2018.05.007.

Erbay, Z., \& Hepbasli, A. (2014). Application of Conventional and Advanced Exergy Analyses to Evaluate the Performance of a Ground-Source Heat Pump (GSHP) Dryer Used in Food Drying. Energy Conversion and Management, 78(2), 499-507. https://doi.org/10.1016/j.enconman.2013.11.009.

Fagbenro, O. (1994). Dried Fermented Fish Silage in Diets for Oreochromis niloticus. The Israeli Journal of Aquaculture Bamidgeh, 46(3), 140-147.

Falcón, M. D., Barrón, J. M., Romero, A. L., \& Domínguez, M. F. (2011). Efecto adverso en la calidad proteica de los alimentos de dietas con alto contenido de fibra dietaria. Revista Chilena de Nutrición, 38(3), 356-367. https://doi.org/10.4067/S0717-75182011000300012.

Falowo, A. B., Mukumbo, F. E., Idamokoro, E. M., Lorenzo, J. M., Afolayan, A. J., \& Muchenje, V. (2018). Multi-Functional Application of Moringa oleifera Lam. in Nutrition and Animal Food Products: A Review. Food Research International, 106(4), 317-334. https://doi.org/10.1016/j.foodres.2017.12.079.

García, M. D., Oruña, L., Domínguez, H., \& Martínez, V. (2005). Evaluación de la calidad proteica de harina de lombriz (Eisenia foetida) en ratas en crecimiento. Revista Cubana de Ciencia Agrícola, 39(3), 333-338.

Ciencia y Agricultura (Cien. Agri.) Vol. 16 (2). L-ISSN 0122-8420. elSSN 2539-0899.

Mayo-Agosto 2019, pp. 79-92. Tunja (Boyacá) - Colombia. DOI:

https://doi.org/10.19053/01228420.v16.n2.2019.9130 
Goddard, J. S., \& Perret, J. S. (2005). Co-Drying Fish Silage for Use in Aquafeeds. Animal Feed Science and Technology, 118(3), 337-342. https://doi.org/10.1016/j.anifeedsci.2004.11.004.

Gunya, B., Masika, P. J., Hugo, A., \& Muchenje, V. (2016). Nutrient Composition and Fatty Acid Profiles of OvenDried and Freeze-Dried Earthworm Eisenia foetida. Journal of Food and Nutrition Research, 4(6), 343348. https://doi.org/10.12691/jfnr-4-6-1.

Gunya, B., Muchenje, V., \& Masika, P. J. (2019). The Potential of Eisenia foetida as a Protein Source on the Growth Performance, Digestive Organs Size, Bone Strength and Carcass Characteristics of Broilers. The Journal of Applied Poultry Research, 0, 1-9. https://doi.org/10.3382/japr/pfy081.

Guptaa, M., Shikhab, K. S., \& Tewaria, S. K. (2014). Quality Evaluation of Vermicompost at Various Phases of Farm Waste Composting and During Storage. Advances in Bioresearch, 5(1), 56-63. https://doi.org/10.15515/abr.0976-4585.5.56-63.

Ibáñez, I. A., Herrera, C. A., Velásquez, L. A., \& Hebel, P. (1993). Nutritional and Toxicological Evaluation on Rats of Earthworm (Eisenia fetida) Meal as Protein Source for Animal Feed. Animal Feed Science and Technology, 42(1-2), 165-172. https://doi.org/10.1016/0377-8401(93)90031-E.

Jiménez, M. E., Coca, S. A., González, J. M., \& Mateos, G. G. (2016). Inclusion of Insoluble Fiber Sources in Mash or Pellet Diets for Young Broilers. 1. Effects on Growth Performance and Water Intake. Poultry Science, 95(1), 41-52. https://doi.org/10.3382/ps/pev309.

Kızılkaya, R., \& Türkay, F. Ş. (2014). Vermicomposting of Anaerobically Digested Sewage Sludge with Hazelnut Husk and Cow Manure by Earthworm Eisenia foetida. Compost Science \& Utilization, 22(2), 68-82. https://doi.org/10.1080/1065657X.2014.895454.

Kuforiji, O. O., Agunbiade, J. A., Awojobi, H. A., \& Eniolorunda, O. O. (2016). Feeding Value of Cassava Products Supplemented with Earthworm Meal in Diets of Growing Rabbits. Tropical Agriculture, 93(3), 197-208.

Langer, S., Bakhtiyar, Y., \& Lakhnotra, R. (2011). Replacement of Fishmeal with Locally Available Ingredients in Diet Composition of Macrobrachium dayanum. African Journal of Agricultural Research, 6(5), 10801084.

Maková, J., Javoreková, S., Elbl, J., Medo, J., Hricáková, N., \& Kováčik, P. (2019). Impact of Vermicompost on Biological Indicators of the Quality of Soil under Maize in a Greenhouse Experiment. Journal of Elementology, 24(1), 319-330. https://doi.org/10.5601/jelem.2017.22.4.1548.

Martínez, Y., Carrión, Y., Rodríguez, R., Valdivié, M., Olmo, C., Betancur, C., \& Liu, G. (2015). Growth Performance, Organ Weights and Some Blood Parameters in Replacement Laying Pullets Fed with Increasing Levels of Wheat Bran. Brazilian Journal of Poultry Science, 17(3), 347-354. http://doi.org/10.1590/1516-635x1703347-354.

Martínez, Y., Li, X., Liu, G., Bin, P., Yan, W., Más, D., Valdivié, M., Hu, C. A., Re, W., \& Yin, Y. L. (2017). The Role of Methionine on Metabolism, Oxidative Stress and Diseases. Amino Acids, 49(12), 2091-2098. https://doi.org///10.1007/s00726-017-2494-2.

Mohanta, K. N., Subramanian, S., \& Korikanthimath, V. S. (2016). Potential of Earthworm (Eisenia foetida) as Dietary Protein Source for Rohu (Labeo rohita) Advanced Fry. Cogent Food \& Agriculture, 2(1), 1138594. https://doi.org/10.1080/23311932.2016.1138594.

Morillo, M., Visbal, T., Altuve, D., Ovalles, F., \& Medina, A. L. (2013). Valoración de dietas para alevines de Colossoma macropomum utilizando como fuentes proteicas harinas: de lombriz (Eisenia foetida), soya (Glycine max) y caraotas (Phaseolus vulgaris). Revista Chilena de Nutrición, 40(2), 147-154. https://doi.org/10.4067/S0717-75182013000200009.

National Research Council -NRC- (1994). Nutrient Requirements of Poultry. (9 ${ }^{\text {th }}$ ed.). Washington: Academy Press.

Ciencia y Agricultura (Cien. Agri.) Vol. 16 (2). L-ISSN 0122-8420. elSSN 2539-0899.

Mayo-Agosto 2019, pp. 79-92. Tunja (Boyacá) - Colombia. DOI:

https://doi.org/10.19053/01228420.v16.n2.2019.9130 
Ncobela, C. N., \& Chimonyo, M. (2015). Potential of Using Non-Conventional Animal Protein Sources for Sustainable Intensification of Scavenging Village Chickens: A Review. Animal Feed Science and Technology, 208, 1-11. https://doi.org/10.1016/j.anifeedsci.2015.07.005

Olmo, C., Martínez, Y., León, E., Leyva, L., Nuñez, M., Rodríguez, R., Labrada, A., Iser, M., Betancur, C., Merlos M., \& Liu, G. (2012). Effect of Mulberry Foliage (Morus alba) Meal on Growth Performance and Edible Portions in Hybrid Chickens. International Journal of Animal and Veterinary Advances, 4(4), 263-268.

Ovalles, J., Medina, A., Márquez, E., \& Rial, L. (2017). Efecto del proceso de secado de la lombriz de tierra (Eisenia andrei) sobre el perfil aminoacídico de la harina determinado por cromatografía. Saber, 29, 486-494. https://doi.org/10.4067/s0717-75182008000300008.

Øverland, M., Mydland, L. T., \& Skrede, A. (2019). Marine Macroalgae as Sources of Protein and Bioactive Compounds in Feed for Monogastric Animals. Journal of the Science of Food and Agriculture, 99(1), 13-24. https://doi.org/10.1002/jsfa.9143

Rezaeipour, V., Nejad, O. A., \& Miri, H. Y. (2014). Growth Performance, Blood Metabolites and Jejunum Morphology of Broiler Chickens Fed Diets Containing Earthworm (Eisenia foetida) Meal as a Source of Protein. International Journal of Advanced Biological and Biomedical Research, 2(8), 2483-2494.

Rojas, O. J., Vinyeta, E., \& Stein, H. H. (2016). Effects of Pelleting, Extrusion, or Extrusion and Pelleting on Energy and Nutrient Digestibility in Diets Containing Different Levels of Fiber and Fed to Growing Pigs. Journal of Animal Science, 94(5), 1951-1960. https://doi.org/10.2527/jas2015-0137.

Sánchez, Y. P., Betancur, H. C., Botello, A. L., Pérez, K. C., Ruiz, C. C., \& Martínez, Y. A. (2019). Ensilability and Chemical Composition of Silages Made with Different Mixtures of Noni (Morinda citrifolia L.). Ciencia y Agricultura, 16(1), 3-16. https://doi.org/10.19053/01228420.v16.n1.2019.8802.

Savón, L., Scull, I., \& Martínez, M. (2007). Integral Foliage Meal for Poultry Feeding. Chemical Composition, Physical Properties and Phytochemical Screening. Cuban Journal of Agricultural Science, 41(2), 359361.

Sharma, K., \& Garg, V. K. (2018). Comparative Analysis of Vermicompost Quality Produced from Rice Straw and Paper Waste Employing Earthworm Eisenia fetida (Sav.). Bioresource Technology, 250, 708-715. https://doi.org/10.1016/j.biortech.2017.11.101.

Singh, R., Srivastava, P., Singh, P., Upadhyay, S., \& Raghubanshi, A. S. (2019). Human Overpopulation and Food Security: Challenges for the Agriculture Sustainability. In Khosrow-Pour. (ed.), Urban Agriculture and Food Systems: Breakthroughs in Research and Practice (pp. 439-467). Pennsylvania, United States: IGI Global. https://doi.org/10.4018/978-1-5225-8063-8.ch022.

Smárason, B. Ö., Alriksson, B., \& Jóhannsson, R. (2018). Safe and Sustainable Protein Sources from the Forest Industry-The Case of Fish Feed. Trends in Food Science \& Technology, 84, 12-14. https://doi.org/10.1016/j.tifs.2018.03.005.

Sogbesan, A. O., \& Ugwumba, A. A. (2008). Nutritional Values of Some Non-Conventional Animal Protein Feedstuffs Used as Fishmeal Supplement in Aquaculture Practices in Nigeria. Turkish Journal of Fisheries and Aquatic Sciences, 8(1), 159-164.

Szukl, P., Podkowaka, Z., Bocianowski, J., Krauklis, D., \& Wilczewska, W. (2018). Chemical Composition and Nutritional Value of Maize Grains from Cultivars of Different Breeding and Seed Companies. Journal of Research and Applications in Agricultural Engineering, 63(4), 203-208.

Tiroesele, B., \& Moreki, J. C. (2012). Termites and Earthworms as Potential Alternative Sources of Protein for Poultry. International Journal for Agro Veterinary and Medical Sciences, 6, 368-76. https://doi.org/10.5455/ijavms.174.

Valverde, D. M. (2010). Usos de la morera (Morus alba) en la alimentación del conejo. El rol de la fibra y la proteína en el tracto digestivo. Agronomía Mesoamericana, 21(2), 357-366. https://doi.org/10.15517/am.v21i2.4900. 
Vidotti, R. M., Carneiro, D. J., \& Viegas, E. (2002). Growth Rate of Pacu, Piaractus mesopotamicus, Fingerlings Fed Diets Containing Co-Dried Fish Silage as Replacement of Fish Meal. Journal of Applied Aquaculture, 12(4), 77-88. https://doi.org/10.1300/J028v12n04 07.

Vielma, R. R., Durán, J. F., León, L. A., \& Medina, A. (2003). Valor nutritivo de la harina de lombriz (Eisenia foetida) como fuente de aminoácidos y su estimación cuantitativa mediante cromatografía en fase reversa (HPLC) y derivatización precolumna con o-ftalaldehído (OPA). Ars Pharmaceutica, 44(1), 4358.

Yang, F., Wang, L., Wang, G., Du, P., \& Zhang, Y. (2015). Organic Matter and Nitrogen Distribution, and Functional Groups of Filter at Earthworm Packing Bed in Vermifiltration. Polish Journal of Environmental Studies, 24(1), 375-380.

Zhenjun, S., Xianchun, L., Lihui, S., \& Chunyang, S. (1997). Earthworm as a Potential Protein Resource. Ecology of Food and Nutrition, 36(2-4), 221-236. https://doi.org/10.1080/03670244.1997.9991517.

Ciencia y Agricultura (Cien. Agri.) Vol. 16 (2). L-ISSN 0122-8420. elSSN 2539-0899.

Mayo-Agosto 2019, pp. 79-92. Tunja (Boyacá) - Colombia. DOI:

https://doi.org/10.19053/01228420.v16.n2.2019.9130 